\title{
KARAKTERISTIK LAHAN DAN KUALITAS KEMANISAN UBI JALAR CILEMBU
}

\author{
Land Characteristics and Sweetness Quality of Cilembu Sweet Potato
}

\author{
Muhammad Amir Solihin ${ }^{\mathrm{a}}$, Santun R.P. Sitorus ${ }^{\mathrm{b}}$, Atang Sutandi ${ }^{\mathrm{b}}$, dan Widiatmaka ${ }^{\mathrm{b}}$ \\ ${ }^{a}$ Departemen Ilmu Tanah dan Sumberdaya Lahan, Fakultas Pertanian, Universitas Padjadjaran, Jatinangor — \\ m.amir.solihin@unpad.ac.id \\ ${ }^{b}$ Departemen Ilmu Tanah dan Sumberdaya Lahan, Fakultas Pertanian, Institut Pertanian Bogor, Kampus IPB \\ Darmaga, Bogor 16680
}

\begin{abstract}
The Cilembu sweet potato is the popular food crop from specific location in Sumedang, West Java. Sweetness degree is one of key indicators for this commodity. Sweetness degree relate to sugar content. Currently, Cilembu sweet potato variety was grown by farmers is Rancing. They were local culture on cultivation and storage of Cilembu sweet potato. Study of Cilembu sweet potato based on land characteristics on cultivation location and sweetness quality along storage periods between different cultivation locations is limited. The objectives of this study were to determined influence of land characteristics of cultivation locations and storage periods on sweetness quality of Cilembu sweet potato. Samples were taken from harvested tubers from Cilembu, Rancakalong, Sukasari, Cicalengka, and Jalaksana cultivation location using purposive sampling method. Sweetness degree was measured by total sugar content using luff schoorl method. The experiment design was used split plot design. The experiment room controlled at the same condition. The storage periods was observed at $0,1,2,3$, and 4 weeks after harvest. The role of land characteristics on the sweetness quality of Cilembu sweet potato was used analysis of regression and t test for equality of means. The result showed that storage periods was significantly affect the sweetness quality of Cilembu sweet potato, while the cultivation locations did not significant influence on sweetness quality. They were not interaction between both factors. The chemical and physical soil properties, elevation and climate properties affect differences of sweetness quality of Cilembu sweet potato on different cultivation locations.
\end{abstract}

Keywords: Cilembu, land characteristic, storage periods, sweet potato, total sugar content.

(Diterima: 03-03-2017; Disetujui: 18-05-2017)

\section{Pendahuluan}

Sumberdaya lahan merupakan faktor biofisik lingkungan yang berperan penting dalam menunjang perkembangan wilayah, terutama sebagai penyangga berbagai aspek kehidupan diantaranya untuk tanaman. Keragaman sifat lahan diantara lokasi yang berbeda berperan pada perbedaan performa pertumbuhan dan produksi tanaman. Salah satu komoditas pertanian yang populer dan diminati konsumen dalam dan luar negeri adalah ubi jalar Cilembu. Ubi jalar Cilembu dikenal berasal dari Desa Cilembu, Kabupaten Sumedang, Jawa Barat. Ubi jalar ini terkenal karena bersifat khas, yaitu memiliki rasa manis dan mengeluarkan cairan yang mengandung gula (Onggo, 2006). Kadar gula, terutama sukrosa, menjadi salah satu indikator andal tingkat kemanisan ubi jalar (Lebot, 2009). Kekhasan ini menjadikan Desa Cilembu, Kabupaten Sumedang mendapatkan sertifikat Indikasi Geografis untuk ubi jalar Cilembu Sumedang. Sentra budidaya ubi jalar Cilembu terdapat di Kecamatan Pamulihan, Tanjungsari, Rancakalong, dan Sukasari. Wilayah-wilayah tersebut merupakan lokasi asal ubi jalar Cilembu (DJKI, 2013).

Beberapa penelitian terdahulu telah dilakukan berkaitan dengan ubi jalar Cilembu varietas Nirkum (Onggo, 2006; Tohidin, 2006; Solihin, 2007; Oktiarni,
2008; Subroto, 2010). Namun, varietas Nirkum saat ini sudah tidak umum lagi dibudidayakan secara komersial dan dipandang oleh petani kurang ekonomis, karena produksi rendah, tumbuh pada lahan tertentu yang terbatas, serta berumur panjang. Saat ini ubi jalar Cilembu yang digunakan oleh petani dan diminati konsumen adalah varietas Rancing. Varietas Rancing ini merupakan pengembangan varietas Nirkum yang disilangkan dengan varietas ubi jalar lainnya yang mempunyai daya adaptasi luas (DJKI, 2013). Studi terdahulu mengungkapkan bahwa diantara lokasi budidaya yang berbeda terdapat keragaman kadar gula ubi jalar Cilembu pada varietas Nirkum (Tohidin, 2006). Hasil penelitian Caliskan et al. (2007) dan Susilawati et al. (2008) menunjukkan bahwa keragaman lingkungan menghasilkan komposisi kimia umbi yang berbeda. Beberapa studi mengungkapkan pengaruh iklim, tanah dan hama pada produksi ataupun kadar gula ubi jalar (Nedunchezhiyan et al., 2012; Ravi dan Saravan, 2012; Liu et al., 2013; Laxminarayana dan John, 2014; Swamy dan Omwenga, 2014; Hue dan Low, 2015; Prabrawardani dan Suparno, 2015).

Fenomena di lapangan menunjukkan bahwa petani dan pedagang ubi jalar Cilembu melakukan penyimpanan minimal satu hingga tiga minggu setelah panen sebelum dibakar atau dijual ke konsumen. Lama penyimpanan yang dilakukan petani atau 
pedagang ubi jalar Cilembu tergantung lokasi asal ubi jalar tersebut. Onggo (2006) mengungkapkan bahwa lama penyimpanan hingga 3 minggu berperan terhadap peningkatan kadar gula ubi jalar Cilembu varietas Nirkum. Hal ini antara lain disebabkan karena selama penyimpanan terjadi hidrolisis pati sebagai polisakarida menjadi disakarida dan monosakarida, yang merupakan sumber kemanisan ubi jalar (Onggo, 2006; Risnoyatiningsih, 2011; Lai et al., 2013; Huang et al., 2014; Kwarteng et al., 2014). Diduga ada peran sifat lahan di lokasi budidaya yang menyebabkan terjadinya perbedaan kualitas ubi jalar Cilembu. Solihin et al. (2016) mengungkapkan adanya faktor tanah dan iklim yang berpengaruh pada ubi jalar Cilembu berdasarkan persepsi petani Cilembu. Dengan latar belakang tersebut, diperlukan analisis peran lokasi budidaya terhadap keragaman keragaan kadar gula total, sebagai indikator utama kualitas ubi jalar Cilembu.

Penelitian ini bertujuan mengetahui kadar gula dan kadar gula total pada beberapa periode lama penyimpanan, serta mengeksplorasi peran keragaman karakteristik lahan di lokasi budidaya terhadap kualitas kemanisan ubi jalar Cilembu varietas Rancing. Kadar gula total pada beberapa periode lama penyimpanan umbi ubi jalar Cilembu akan dianalisis. Penelitian ini diharapkan dapat memberikan informasi yang berguna untuk mengetahui peran karakteristik lahan di lokasi budidaya terhadap kadar gula total ubi jalar Cilembu, khususnya varietas Rancing serta memberikan penjelasan ilmiah terhadap fenomena yang terjadi.

\section{Metode}

\subsection{Deskripsi lokasi studi}

Studi dilakukan terhadap ubi jalar Cilembu yang diperoleh dari hasil panen pada plot percobaan di sentra budidaya ubi jalar Cilembu di Kecamatan Cilembu, Sukasari, Rancakalong (Kabupaten Sumedang), Cicalengka (Kabupaten Bandung) dan Jalaksana (Kabupaten Kuningan). Pemilihan lokasi ini mempertimbangkan lokasi budidaya sebagai pewakil lokasi tipikal (di Desa Cilembu), lokasi tipikal di luar Desa Cilembu (Sukasari dan Rancakalong), dan lokasi non tipikal (area pengembangan baru di Cicalengka Kabupaten Bandung dan Jalaksana Kabupaten Kuningan). Lokasi budidaya terletak pada tanah berbahan induk vulkan (Silitonga, 2003). Umumnya ordo tanahnya adalah Inceptisols, kecuali tanah di lokasi Jalaksana tergolong ordo Entisols (Solihin, 2017). Lokasi studi termasuk beriklim tropis basah dengan curah hujan tahunan rata-rata sebesar 2105.17 mm tahun ${ }^{-1}$ (Stasiun Lapan Haurgombong, Stasiun Klimatologi Unpad, Stasiun Curah Hujan BBWS Citarum).

\subsection{Sampel tanah dan analisis}

Karakteristik lahan yang diamati meliputi sifat tanah, iklim, dan topografi. Sampel tanah diambil dari 5 lokasi sentra budidaya ubi jalar Cilembu varietas Rancing. Sampel tanah komposit dikumpulkan dari 5 titik dalam plot secara diagonal pada kedalaman tanah 0-25 cm, dicampur dan diambil dengan metode quarter sekitar $1 \mathrm{~kg}$. Analisis mengikuti prosedur teknis analisis tanah dari Balai Penelitian Tanah (2009). Karakteristik tanah yang diukur meliputi: pH, C-organik, $\mathrm{N}$ total, fosfor (P), kalium (K), kalsium (Ca), magnesium (Mg), kapasitas tukar kation (KTK), kejenuhan basa (KB), dan tekstur tanah. Analisis dilakukan di Laboratorium Kesuburan Tanah Fakultas Pertanian Universitas Padjadjaran. Karakteristik lahan yang diukur di lapangan meliputi: elevasi, kedalaman efektif tanah. Data iklim diperoleh dari stasiun iklim terdekat, yaitu: temperatur udara dan curah hujan bulanan sepanjang periode tumbuh ubi jalar Cilembu. Data elevasi lokasi sampel diperoleh dari peta topografi dan pengukuran koordinat lokasi dengan menggunakan GPS.

\subsection{Sampel ubi jalar Cilembu dan analisisnya}

Penelitian ini menggunakan sampel ubi jalar (Ipomoea batatas L.) lokal Cilembu varietas Rancing yang ditanam pada plot percobaan di lokasi sentra budidaya tipikal dan non tipikal dengan input pemupukan NPK masing-masing 200 kg.ha-1, pengolahan tanah dan varietas sama, serta dipanen pada umur 4.5 bulan. Ubi jalar Cilembu yang digunakan dalam perlakuan dan analisis kadar gula total merupakan ubi mentah hasil panen. Analisis kadar gula total sampel ubi jalar Cilembu dilakukan mengacu pada SNI 01-2892-1992 tentang cara uji gula dengan menggunakan metode Luff Schoorl (BSN, 1992).

Penyimpanan sampel ubi jalar mentah hasil panen dicuci dengan air bersih dan dikeringudarakan. Penyimpanan ubi jalar dilakukan dengan tata letak secara acak berkelompok pada keranjang bambu. Ruang penyimpanan memiliki suhu rerata $25{ }^{\circ} \mathrm{C}$, kelembaban rerata $70 \%$, serta memiliki sirkulasi udara lancar dan tidak terkena panas sinar matahari secara langsung. Durasi penyimpanan dilakukan sesaat setelah panen hingga empat minggu setelah panen. Pembatasan waktu maksimum penyimpanan ubi berkaitan dengan morfologi kulit ubi jalar Cilembu yang tipis berdampak pada kerentanan terhadap serangan hama Lanas (Cylas formicarius Sp.) selama penyimpanan umbi sehingga dipertimbangkan hanya hingga empat minggu setelah panen.

\subsection{Desain penelitian dan kombinasi perlakuan}

Percobaan dirancang dengan menggunakan rancangan petak terbagi (Split Plot Design) dengan dua faktor terdiri atas lokasi budidaya dan lama penyimpanan dengan tiga ulangan. Faktor lokasi 
budidaya sebagai petak utama sebanyak lima taraf terdiri atas: Cilembu, Rancakalong, Sukasari, Cicalengka dan Jalaksana. Faktor lama penyimpanan umbi setelah panen sebagai anak petak sebanyak lima taraf terdiri atas: 0, 1, 2, 3, 4 minggu setelah panen (MSP). Analisis ini dilakukan untuk mengetahui pengaruh lokasi budidaya terutama sifat tanah terhadap kadar gula total ubi jalar Cilembu.

Rancangan petak terbagi menggunakan model persamaan regresi sebagai berikut (Gaspersz, 1991):

$\mathrm{Y}_{\mathrm{ijk}}=\mu+\rho_{\mathrm{k}}+\alpha_{\mathrm{i}}+\beta_{\mathrm{j}}+v_{\mathrm{ik}}+(\alpha \beta)_{\mathrm{ij}}+\varepsilon_{\mathrm{ijk}}$

di mana: $\mathrm{i}=1,2, \ldots . ., \mathrm{a} ; \mathrm{j}=1,2, \ldots . ., \mathrm{b} ; \mathrm{k}=1,2, \ldots .$. , $\mathrm{r} ; \mathrm{Y}_{\mathrm{ijk}}=$ Nilai pengamatan ke-k dari kombinasi perlakuan taraf ke-i dari faktor lokasi budidaya dan taraf ke-j dari faktor lama penyimpanan; $\mu=$ Nilai tengah populasi (rata-rata sesungguhnya); $\alpha_{i}=$ Pengaruh aditif taraf ke-i lokasi budidaya; $\beta_{\mathrm{j}}=$ Pengaruh aditif taraf ke-j lama penyimpanan; $(\alpha \beta)_{\mathrm{ij}}=$ Pengaruh aditif dari taraf ke-1 dari lokasi budidaya dan taraf ke-j dari lama penyimpanan; $v_{\text {ik }}=$ pengaruh galat dari petak utama; $\varepsilon_{\mathrm{ijk}}=$ Pengaruh galat pada pengamatan ke-k dari kombinasi perlakuan ij

\subsection{Analisis Statistik}

Data hasil pengamatan diolah, dianalisis dan disajikan dalam bentuk tabel, gambar, dan persamaan dengan mengunakan Microsoft Office Excel 2007. Berdasarkan model persamaan rancangan petak terbagi, setiap pengamatan diuji hipotesis untuk mengetahui pengaruh lokasi budidaya, pengaruh lama penyimpanan, dan pengaruh interaksi lokasi budidaya dan lama penyimpanan terhadap kadar gula total ubi jalar Cilembu. Terhadap data hasil pengamatan terlebih dahulu dilakukan uji normalitas dengan Kolmogorov-Smirnov dan uji homogenitas atau uji Levene. Apabila data berdistribusi normal, maka dilakukan uji signifikan dengan uji $\mathrm{F}$ pada tingkat signifikan $\alpha=0.05$. (Gaspersz, 1991). Uji beda nyata untuk data berdistribusi normal dilakukan uji Tukey dengan tingkat signifikan $\alpha=0.05$.

Selain ditampilkan keragaannya, data produksi juga dianalisis menggunakan analisis regresi untuk mengetahui kadar gula total maksimum dan lama waktu pencapaiannya yang diperoleh dari setiap lokasi budidaya. Data lahan dianalisis dengan uji perbandingan dan dibahas secara deskriptif untuk mengkaji lebih lanjut peran lokasi budidaya terutama berdasarkan pada perbedaan karakteristik lahannya terhadap kualitas kemanisan ubi jalar Cilembu. Analisis normalitas, homogenitas, sidik ragam, dan uji beda nyata Tukey dilakukan dengan menggunakan aplikasi SPSS.

\section{Hasil dan Pembahasan}

\subsection{Kadar gula ubi jalar Cilembu}

Kadar gula total hasil analisis disajikan pada Tabel 1. Secara deskriptif diketahui terdapat keragaman kadar gula total ubi jalar Cilembu diantara lokasi budidaya. Rerata kadar gula total seluruh pengamatan pada setiap lokasi budidaya dari tertinggi hingga terendah berturut-turut adalah Cilembu (3.27), Sukasari (3.16), Rancakalong (3.05), Cicalengka (2.95), dan Jalaksana (2.85). Perbedaan kadar gula dapat berkaitan dengan sifat lahan (Ravi dan Saravan, 2012). Kadar gula terendah terdapat di lokasi Jalaksana yang memiliki kendala kondisi KTK tanah rendah, tekstur berpasir dan kedalaman efektif tanah dangkal

Tabel 1. Kadar gula total ubi jalar Cilembu pada beberapa lokasi budidaya, serta lama penyimpanan umbi setelah panen

\begin{tabular}{lcccccc}
\hline \multirow{2}{*}{ Lokasi } & \multicolumn{7}{c}{ Lama penyimpanan setelah panen } \\
\cline { 2 - 5 } & T0 & T1 & T2 & T3 & T4 & \\
\hline \multirow{7}{*}{ Cilembu } & 2.71 & 3.17 & 3.37 & 3.50 & 3.59 & 3.27 \\
Rancakalong & 2.50 & 2.95 & 3.09 & 3.28 & 3.39 & 3.04 \\
Sukasari & 2.57 & 3.06 & 3.19 & 3.43 & 3.55 & 3.16 \\
Cicalengka & 2.36 & 2.79 & 3.09 & 3.30 & 3.23 & 2.95 \\
Jalaksana & 2.30 & 2.77 & 3.06 & 3.13 & 3.06 & 2.87 \\
\hline Rerata & 2.49 & 2.95 & 3.18 & 3.34 & 3.36 & 3.06 \\
\hline
\end{tabular}

$\mathrm{T} 0=$ Saat panen; T1=Minggu ke-1; T2=Minggu ke-2; T3=Minggu ke-3; T4=Minggu ke-4; ${ }^{a}$ Kadar gula total merupakan rerata dari tiga ulangan

\subsection{Pengaruh lokasi budidaya terhadap kadar gula total ubi jalar Cilembu}

Pada Tabel 2 dapat diketahui nilai $F_{\text {hitung }}$ lokasi budidaya ubi jalar (2.10) lebih kecil dari nilai $\mathrm{F}_{\text {tabel }}$ pada taraf nyata $\alpha=0.05$ (3.84). Dengan demikian, lokasi budidaya tidak berpengaruh nyata terhadap kadar gula total ubi jalar Cilembu. Hal ini diduga karena lokasi studi sama-sama terletak pada tanah dari bahan induk vulkanik muda. Umumnya tanah demikian memiliki kesuburan tanah yang cukup baik karena berasal dari mineral yang mudah lapuk dan cukup dapat memberikan suplai hara bagi tanaman. Hal ini dapat ditunjukkan oleh nilai KTK sedang sampai tinggi, $\mathrm{KB}$ tinggi, dan $\mathrm{pH}$ agak masam sampai netral di sebagian besar lokasi studi.

Tabel 2. Analisis sidik ragam pengaruh lokasi asal budidaya dan lama penyimpanan ubi pada kadar gula total ubi jalar Cilembu

\begin{tabular}{|c|c|c|c|c|c|c|c|}
\hline \multirow{2}{*}{$\begin{array}{l}\text { Sumber } \\
\text { Keragaman }\end{array}$} & \multirow{2}{*}{ DB } & \multirow{2}{*}{$\mathrm{JK}$} & \multirow{2}{*}{$\mathrm{KT}$} & \multirow{2}{*}{ F hitung } & \multirow{2}{*}{ Sig. } & \multicolumn{2}{|c|}{ F Tabel } \\
\hline & & & & & & 0.05 & 0.01 \\
\hline \multicolumn{8}{|l|}{ Petak Utama } \\
\hline Kelompok & 2 & 0.15 & 0.0\{ & - & & & \\
\hline Lokasi (L) & 4 & 1.55 & 0.3 ! & 2.10 & tn & 3.84 & 7.01 \\
\hline Galat L & 8 & 1.48 & $0.1 \xi$ & & & & \\
\hline \multicolumn{8}{|l|}{ Anak Petak } \\
\hline Waktu (T) & 4 & 7.67 & $1.9^{\prime}$ & 179.98 & $* *$ & 2.61 & 3.83 \\
\hline $\begin{array}{l}\text { Interaksi } \\
(\mathrm{LT})\end{array}$ & 16 & 0.16 & 0.0 & 0.58 & tn & 1.90 & 2.48 \\
\hline Galat T & 32 & 0.56 & $0.0^{\prime}$ & & & & \\
\hline Jumlah & 74 & 11.65 & & & & & \\
\hline
\end{tabular}


Namun demikian, lokasi budidaya di Jalaksana berbeda dengan lokasi lainnya, karena berada pada tanah yang baru berkembang (Entisols) (Solihin, 2017) dengan sifat tanah KTK rendah, KB sangat tinggi, tekstur berpasir, kedalaman efektif tanah dangkal. Sifat tanah di lokasi Jalaksana ini sejalan dengan kadar gula total yang terendah dibandingkan dengan lokasi lainnya. Ini dapat disebabkan karena lokasi budidaya terletak pada area lereng atas gunung Ciremai yang bersolum tipis serta adanya proses erosi aktif di lokasi studi sehingga tanah yang tersisa lebih dominan berupa fraksi pasir, sementara fraksi yang lebih halus terbawa erosi ke lereng bawah. Fraksi dominan pasir berperan pada KTK yang rendah sehingga hara tanah mudah tercuci. Hal tersebut dapat menyebabkan kemampuan menahan hara tanah rendah walaupun kejenuhan basa tinggi dari pencucian hara dari wilayah atas lahan. Kondisi sifat kimia tanah (Ravi dan Saravanan, 2012) dan tekstur tanah (Wu et al., 2011) berpengaruh pada hasil tanaman.

Hasil tersebut berbeda dengan hasil penelitian terdahulu bahwa ubi jalar Cilembu varietas Nirkum mempunyai perbedaan kadar gula di antara lokasi budidaya yang berbeda (Tohidin, 2006), tetapi menurut Çaliskan et al. (2007), varietas yang berbeda pada lingkungan yang berlainan menyebabkan hasil dan kualitas ubi jalar yang berlainan. Hal ini dapat berkaitan dengan sifat umum ubi jalar yang mempunyai daya adaptasi tinggi terhadap keragaman lingkungan di Indonesia (Widodo et al., 2015). Wawancara dengan petani ubi Cilembu terungkap bahwa ketika ubi jalar Nirkum sulit dibudidayakan secara luas dan kurang ekonomis, petani setempat mencoba persilangan ubi jalar Nirkum dengan ubi jalar lain dan salah satunya dihasilkan Rancing. Sejak tahun 2015, penanaman ubi jalar Cilembu varietas Rancing mulai meluas ke luar Desa Cilembu untuk memenuhi kebutuhan pasar yang tinggi.

Salah satu faktor lain yang menjadi permasalahan utama budidaya ubi jalar Cilembu di lokasi studi adalah hama terutama lanas. Hue dan Low (2015) mengungkapkan bahwa hama lanas (Cylas formicarius Sp.) menjadi salah satu penyumbang terbesar penurunan produksi dan kualitas ubi jalar. Selain itu, lanas juga memicu produksi terpentin pada ubi jalar (Swamy dan Omwenga, 2014; Hue dan Low, 2015) sehingga menyebabkan penurunan kualitas ubi jalar dan terasa pahit jika dimakan.

\subsection{Pengaruh lama penyimpanan terhadap kadar gula total ubi jalar Cilembu}

Tabel 2 menunjukkan bahwa nilai $F_{\text {hitung }}$ perlakuan lama penyimpanan ubi jalar (179.98) lebih besar dari nilai $F_{\text {tabel }}$ pada taraf nyata $1 \%$ (3.83). Hal ini menunjukkan minimal terdapat satu perlakuan lama penyimpanan yang mempengaruhi kadar gula total ubi jalar Cilembu varietas Rancing. Untuk mengetahui perlakuan yang menyebabkan adanya perbedaan signifikan pada kadar gula total ubi jalar Cilembu digunakan hipotesis uji lanjut sebagai berikut: $\mathrm{H}_{0}: \mu \mathrm{A}$ $=\mu \mathrm{B}$ atau $\mathrm{H}_{0}: \mu \mathrm{A}>\mu \mathrm{B}$ di mana $\mu \mathrm{A}=$ rerata data percobaan; $\mu \mathrm{B}=$ Rerata data kontrol. Kriteria pengujian hipotesis, yaitu: terima $\mathrm{H}_{0}$ jika $\mathrm{Qh}>\mathrm{Qt}$ atau tolak $\mathrm{H}_{0}$ jika $\mathrm{Qh}<\mathrm{Qt}$ di mana: $\mathrm{Qh}=$ Nilai hasil hitung; Qt = Nilai tabel.

Berdasarkan hasil uji Tukey (Tabel 3), diketahui bahwa nilai Qh < Qt, sehingga dapat disimpulkan bahwa terdapat perbedaan signifikan pada hampir semua perlakuan lama penyimpanan (T). Kadar gula total saat panen $\left(\mathrm{T}_{0}\right)$ sampai dua minggu setelah panen $\left(\mathrm{T}_{2}\right)$ berbeda signifikan dengan satu sampai empat minggu setelah panen. Hal ini selaras dengan hasil penelitian Onggo (2006) pada ubi jalar Cilembu varietas Nirkum, serta Lai et al. (2013), Huang et al. (2014), dan Kwarteng et al. (2014) pada beberapa varietas ubi jalar asal Taiwan. Namun demikian, kadar gula ubi jalar Cilembu antara tiga $\left(\mathrm{T}_{3}\right)$ dengan empat $\left(\mathrm{T}_{4}\right)$ minggu setelah panen tidak berbeda signifikan.

Tabel 3. Uji beda nyata lama penyimpanan ubi jalar Cilembu setelah panen terhadap kadar gula total

\begin{tabular}{lccccc}
\hline & T0 & T1 & T2 & T3 & T4 \\
\hline T0 & - & & & & \\
T1 & $0.46^{*}$ & - & & & \\
T2 & $0.67^{*}$ & $0.21^{*}$ & - & & \\
T3 & $0.84^{*}$ & $0.38^{*}$ & $0.17^{*}$ & - & \\
T4 & $0.88^{*}$ & $0.42^{*}$ & $0.20^{*}$ & 0.04 & - \\
\hline
\end{tabular}

$\mathrm{T} 0=$ Saat panen; $\mathrm{T} 1=$ Minggu ke-1; $\mathrm{T} 2=$ Minggu ke-2; T3=Minggu ke-3; T4=Minggu ke-4; ${ }^{*}$ Berbeda signifikan pada tingkat $\alpha=0.05$

Peningkatan kadar gula ubi jalar setelah panen terjadi karena adanya proses hidrolisis pati oleh enzim amylase menjadi sukrosa, fruktosa, dan glukosa (Oktiarni, 2008). Gula total pada ubi jalar mentah terdiri atas sukrosa, fruktosa, glukosa dan maltosa (Huang et al., 2014), namun sukrosa lebih dominan (Lai et al., 2013). Hal ini yang menyebabkan kadar gula total ubi jalar pada saat panen $\left(\mathrm{T}_{0}\right)$ sampai dua minggu setelah panen $\left(\mathrm{T}_{2}\right)$ mengalami peningkatan sebesar $17-20 \%$. Selanjutnya terjadi penurunan laju peningkatan kadar gula total ubi jalar di semua lokasi dengan peningkatan sebesar $3-11 \%$ per minggu, bahkan di Cicalengka dan Jalaksana terjadi penurunan kadar gula total setelah minggu ke tiga setelah panen $\left(\mathrm{T}_{3}\right)$. Penurunan kadar gula pada ubi jalar selama penyimpanan dijelaskan oleh Lebot (2009) antara lain disebabkan karena ubi jalar mentah mengalami respirasi sehingga terjadi degradasi pati menjadi $\mathrm{CO}_{2}$, $\mathrm{H}_{2} \mathrm{O}$, dan energi panas. Pada proses ini glukosa pada umbi ubi jalar digunakan sebagai sumber energi pada proses respirasi.

Perbedaan kualitas kemanisan (kadar gula) selama penyimpanan pada ubi jalar Cilembu berbeda dengan hasil penelitian Onggo (2006) pada varietas Nirkum. Hal ini diduga karena pada varietas Rancing, kadar pati yang dapat dihidrolisis menjadi gula sederhana jumlahnya lebih sedikit dibandingkan dengan Nirkum. Komposisi kadar gula bervariasi diantara varietas ubi jalar yang berbeda (Lai et al., 2013; Shekhar, 2015), termasuk lama penyimpanan umbi setelah panen (Kwarteng et al., 2014). Ravi dan Saravan (2012) menjelaskan kadar pati dan aktivitas enzim berlainan 
untuk varietas yang berbeda. Hal ini dapat juga disebabkan jumlah dan aktivitas enzim amilase yang berbeda diantara varietas yang berbeda, seperti yang diungkapkan Oktiarni (2008) pada ubi jalar Nirkum dan Lampenang. Varietas Rancing termasuk ubi jalar dengan durasi tumbuh pendek atau sedang, sedangkan Nirkum termasuk durasi panjang. Hal ini pernah dibahas oleh Ravi dan Saravan (2012) yang menyatakan bahwa durasi pertumbuhan berpengaruh pada produksi ubi jalar.

Selain faktor tanaman dan lama penyimpanan, perbedaan tingkat kemanisan ubi jalar dipengaruhi oleh perbedaan karakteristik lahan di antara lokasi budidaya seperti pada hasil penelitian ubi jalar Cilembu (Tohidin, 2006; Nedunchezhiyan et al., 2012) walaupun pada penelitian ini menunjukkan tidak terdapat pengaruh yang signifikan akibat zona lingkungan, karena cakupan lokasi studi masih relatif sempit.

\subsection{Pengaruh interaksi lokasi budidaya dan lama penyimpanan terhadap kadar gula total ubi jalar Cilembu}

Pada Tabel 2 terdahulu diketahui bahwa $F_{\text {hitung }}$ interaksi lokasi asal budidaya dan lama penyimpanan ubi jalar (0.58) lebih kecil dari nilai $F_{\text {tabel }}$ pada taraf nyata $\alpha=0.05$ (1.90). Hal ini menunjukkan bahwa tidak ada interaksi antara lokasi budidaya dan lama penyimpanan terhadap kadar gula total ubi jalar Cilembu, walaupun secara deskriptif terdapat perbedaan kadar gula total dan sifat lahan diantara lokasi produksi. Peningkatan kadar gula ubi jalar Cilembu (mentah) lebih dominan disebabkan karena lama penyimpanan setelah panen. Hasil ini berbeda dengan hasil penelitian Tohidin (2006) yang menunjukkan bahwa ubi jalar Cilembu mempunyai kadar gula total yang berbeda diantara lokasi budidaya yang berlainan. Hal ini diduga karena sifat lahan di lokasi studi masih berada pada kisaran zona lingkungan yang hampir sama, yaitu pada zona bahan induk, iklim dan topografi yang relatif hampir seragam. Selain faktor lahan, adanya perbedaan dengan penelitian terdahulu disebabkan adanya perbedaan varietas ubi jalar Cilembu yang digunakan, yaitu pada penelitian terdahulu menggunakan varietas Nirkum, sedangkan pada penelitian ini menggunakan varietas Rancing. Penelitian terdahulu menunjukkan bahwa varietas yang berbeda akan menghasilkan komposisi kimia yang berbeda (Onggo, 2006; Liu et al., 2013; Lai et al., 2013; Kwarteng et al., 2014).

\subsection{Peran karakteristik lahan di lokasi budidaya terhadap kualitas kemanisan ubi jalar Cilembu}

Hasil percobaan penelitian menunjukkan bahwa faktor lokasi budidaya tidak berpengaruh signifikan terhadap kadar gula total ubi jalar Cilembu. Namun demikian, pada keragaan kadar gula total dari lokasi budidaya yang berbeda selama periode penyimpanan ubi jalar Cilembu hingga empat minggu setelah panen, rerata kadar gula total di seluruh lokasi studi umumnya mengalami kenaikan yang berbeda-beda (Gambar 1). Hal ini menunjukkan adanya proses hidrolisis pati menjadi gula sederhana seiring lama penyimpanan ubi jalar Cilembu yang berbeda diantara lokasi yang berbeda. Selain itu, lama penyimpanan setelah panen cenderung akan mencapai titik puncak kadar gula total pada waktu yang berbeda pada lokasi budidaya ubi jalar Cilembu yang berbeda.

Berdasarkan grafik pada Gambar 1, selanjutnya dirumuskan persamaan kecenderungan kadar gula total masing-masing lokasi budidaya (Tabel 4).

Pada Tabel 4 diketahui bahwa titik puncak dan mulai terjadinya penurunan rerata kadar gula total ubi jalar Cilembu terjadi pada lama penyimpanan T3 (3 minggu setelah panen) lebih 5 hari atau 26 hari setelah panen. Rerata kadar gula total tertinggi adalah $3.36 \%$. Kadar gula total pada titik puncak di lokasi tipikal cenderung lebih tinggi dari rerata kadar gula total di seluruh lokasi studi, yaitu Cilembu (3.57\%), Rancakalong (3.41\%) dan Sukasari (3.45\%). Sebaliknya, kadar gula total pada titik puncak di lokasi non tipikal menunjukkan nilai lebih rendah dari nilai rerata di seluruh lokasi studi, yaitu Cicalengka $(3.05 \%)$ dan Jalaksana (2.95\%).

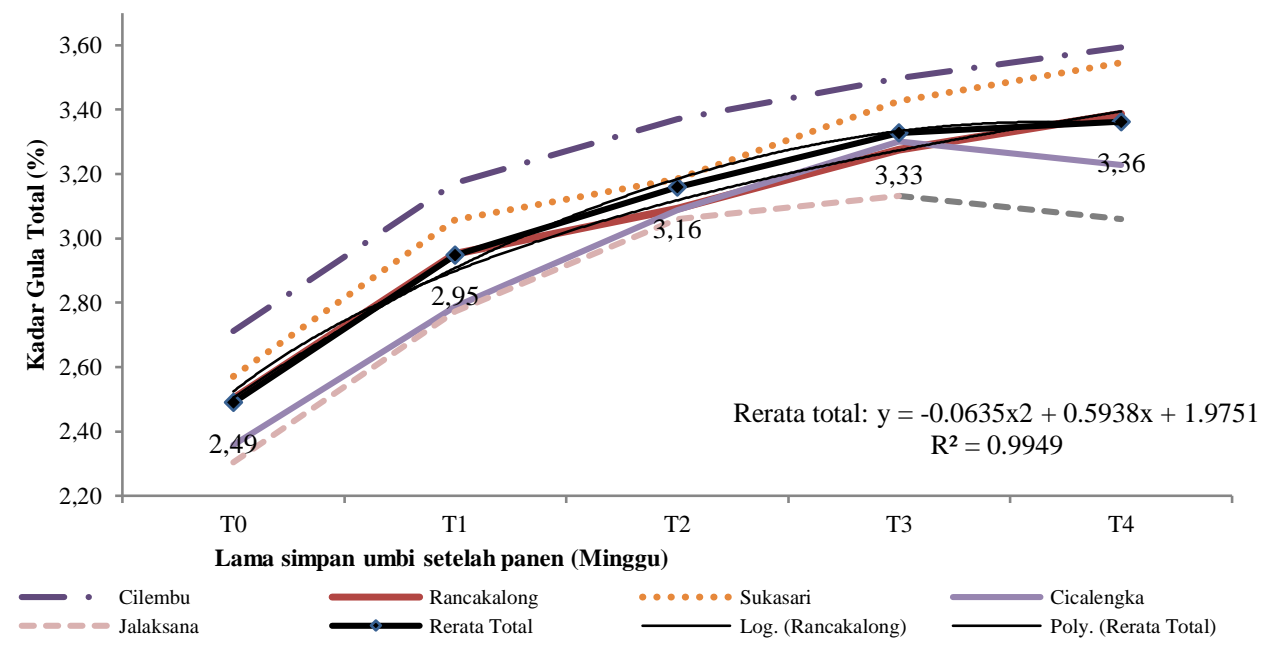

Gambar 1. Grafik kadar gula total ubi jalar Cilembu 
Tabel 4. Titik puncak kadar gula total dan lama penyimpanan ubi jalar Cilembu

\begin{tabular}{|c|c|c|c|c|}
\hline \multirow{2}{*}{ Lokasi } & \multirow{2}{*}{ Fungsi ${ }^{\mathrm{a}}$} & \multirow{2}{*}{$\mathrm{R}^{2}$} & \multicolumn{2}{|c|}{ Titik Puncak } \\
\hline & & & Kadar Gula Total (\%) & $\mathrm{HSP}^{\mathrm{b}}$ \\
\hline Cilembu & $y=-0.0572 x^{2}+0.5517 x+2.2427$ & 0.99 & 3.57 & 27 \\
\hline Rancakalong & $y=-0.0454 x^{2}+0.4817 x+2.096$ & 0.98 & 3.41 & 30 \\
\hline Sukasari & $y=-0.0444 x^{2}+0.4983 x+2.151$ & 0.99 & 3.45 & 32 \\
\hline Cicalengka & $y=-0.0779 x^{2}+0.6926 x+1.731$ & 0.99 & 3.05 & 24 \\
\hline Jalaksana & $y=-0.0925 x^{2}+0.7422 x+1.6564$ & 0.99 & 2.95 & 21 \\
\hline Rerata & $\mathrm{y}=-0.0635 \mathrm{x}^{2}+0.5938 \mathrm{x}+1.9751$ & 0.99 & 3.36 & 26 \\
\hline
\end{tabular}

${ }^{\mathrm{a}}$ Fungsi kuadratik; ${ }^{\mathrm{b}} \mathrm{HSP}=$ Hari Setelah Panen; $\mathrm{R}^{2}=$ Koefisien determinasi

Berdasarkan lama waktu simpan ubi jalar Cilembu pada saat mencapai kadar gula total pada titik puncak menunjukkan umumnya terjadi pada minggu ke-4 setelah panen untuk lokasi tipikal dan minggu ke-3 untuk lokasi non tipikal. Lama simpan umbi pada titik puncak kadar gula total di lokasi tipikal lebih tinggi dari rerata di seluruh lokasi studi, berturut-turut dari yang tercepat hingga terlama yaitu Cilembu (hari ke27 setelah panen), Rancakalong (hari ke-30 setelah panen), dan Sukasari (hari ke-32 setelah panen). Sebaliknya, lama simpan umbi di lokasi non tipikal lebih rendah dari rerata lama simpan di seluruh lokasi studi, yaitu di Cicalengka (hari ke-24 setelah panen) dan di Jalaksana (hari ke-21 setelah panen).

Hasil analisis ini menunjukkan bahwa lokasi budidaya ubi jalar Cilembu yang berbeda memberikan kadar gula total dan lama simpan maksimal yang berbeda-beda, dimana ubi jalar Cilembu di lokasi tipikal kadar gulanya lebih tinggi dan lama waktu simpan pada titik puncak lebih lama dibandingkan yang dibudidayakan di lokasi non tipikal. Hal ini menunjukkan faktor lahan di lokasi studi berperan terhadap perbedaan kualitas kemanisan ubi jalar Cilembu walaupun berada pada zona lingkungan yang hampir sama.

Berdasarkan uji perbandingan karakteristik lahan diantara lokasi budidaya (Tabel 5), diketahui bahwa terdapat beberapa karakteristik lahan yang berbeda signifikan diantara lokasi tipikal ubi jalar Cilembu di Desa Cilembu, tipikal di luar Desa Cilembu (Rancakalong dan Sukasari), serta lokasi non tipikal atau lokasi budidaya baru (Cicalengka dan Jalaksana). Perbedaan signifikan dalam hal karakteristik lahan terdapat pada sifat kimia tanah, sifat fisik tanah, elevasi dan iklim.

Perbedaan signifikan antara lokasi tipikal dengan lokasi non tipikal diantaranya adalah sifat kimia tanah, fisik tanah, elevasi dan iklim. Sifat kimia tanah yang berbeda signifikan adalah $\mathrm{pH}$ dan kejenuhan basa. Sifat fisik tanah yang berbeda signifikan adalah fraksi klei dan kedalaman efektif tanah. Aspek elevasi yang berbeda signifikan adalah ketinggian tempat. Sifat iklim yang berbeda signifikan adalah temperatur maksimum, temperatur minimum, dan selisih temperatur maksimum dan minimum. Selain faktor temperatur, curah hujan bulan ke-3 dan ke-4 periode tumbuh juga menunjukkan berbeda signifikan diantara lokasi tipikal dengan lokasi non tipikal.
Ubi jalar Cilembu varietas Rancing, mempunyai kualitas kemanisan tinggi pada $\mathrm{pH}$ tanah agak masam dibandingkan netral atau agak basa. Hal ini berkaitan dengan ketersediaan hara terutama unsur mikro yang optimal pada $\mathrm{pH}$ agak masam-netral. Beberapa unsur hara berperan sebagai aktivator enzim (Dutta et al., 2006) dan enzim ini berperan pada peningkatan kadar gula ubi jalar (Oktiarni, 2008).

Sifat kimia tanah lainnya yaitu kejenuhan basa berperan sebagai indikator ketersediaan kation basa bagi tanaman. Kejenuhan basa yang tinggi umumnya terjadi pada tanah vulkanik muda dengan tingkat pencucian yang tinggi dan terakumulasi di lahan percobaan pada tanah dengan kedalaman efektif dangkal, namun konsentrasi tinggi kation basa seperti di lokasi non tipikal, dapat menghambat ketersediaan unsur hara lainnya (Hardjowigeno, 2007).

Sifat fisik tanah berupa fraksi klei berperan penting dalam media perakaran. Ubi jalar Cilembu menghendaki tekstur tanah yang halus dibandingkan tekstur kasar. Hal ini berkaitan dengan peran klei sebagai koloid tanah dalam menyangga dan menyediakan hara bagi tanaman, sedangkan pasir bersifat kurang aktif dalam mempertukarkan ataupun menyangga kation dalam tanah. Selain itu Wu et al. (2011) mengungkapkan bahwa tekstur klei lebih baik dari pada pasir dalam menunjang kadar air tersedia dalam tanah. Selain aspek tekstur, kedalaman efektif tanah berperan penting bagi pertumbuhan akar dan umbi dalam tanah. Adanya hambatan kondisi perakaran seperti adanya batuan padas akan menghambart pergerakan hara dan pertumbuhan umbi.

Faktor ketinggian tempat lokasi budidaya berkaitan dengan perbedaan temperatur siang dan malam. Pada wilayah dengan keragaman ketinggian tempat yang besar, ketinggian tempat dan arah lereng mempengaruhi iklim mikro setempat (Siswanto, 2006). Faktor temperatur ini berperan pada pembentukan umbi dan akumulasi kadar gula. Ubi jalar Cilembu menghendaki temperatur maksimum yang lebih rendah tetapi selisih dengan temperatur minimal tidak terlalu besar atau berada pada temperatur rerata $24.4{ }^{\circ} \mathrm{C}$ sehingga optimum untuk akumulasi gula dan pembentukan umbinya.

Solihin et al. (2016) menunjukkan ubi jalar Cilembu menghendaki temperatur maksimum yang tidak terlalu tinggi $\left( \pm 28.2^{\circ} \mathrm{C}\right)$ pada siang hari ketika terjadi proses fotosintesis dan temperatur minimum 
yang lebih rendah $\left( \pm 14.6{ }^{\circ} \mathrm{C}\right)$ ketika terjadi proses pembentukan umbi pada malam hari. Hal ini mendekati kondisi yang diungkapkan Ramirez (1995) bahwa pertumbuhan vegetatif pada siang hari dengan temperatur 20-25 ${ }^{\circ} \mathrm{C}$, sedangkan akumulasi hasil fotosintesis pada akar tanaman ubi jalar ketika temperatur malam $15-20{ }^{\circ} \mathrm{C}$.

Tabel 5. Perbandingan karakteristik lahan di lokasi tipikal dan non tipikal ubi jalar Cilembu

\begin{tabular}{|c|c|c|c|c|}
\hline Sifat Lahan & Satuan & Rerata & Lokasi & Non Tipikal (Uji t) * \\
\hline \multirow[t]{3}{*}{$\overline{\mathrm{pH} \mathrm{H}} \mathrm{H}_{2} \mathrm{O}$} & & 6.13 & Tipikal di Cilembu & $0.0^{*}$ \\
\hline & & 6.08 & Tipikal di Luar Cilembu & $0.0^{*}$ \\
\hline & & 7.3 & Non Tipikal & - \\
\hline \multirow[t]{3}{*}{ C-organik } & $\%$ & 1.3 & Tipikal di Cilembu & 0.82 \\
\hline & & 1.54 & Tipikal di Luar Cilembu & 0.06 \\
\hline & & 1.24 & Non Tipikal & - \\
\hline \multirow[t]{3}{*}{ Ntot } & $\%$ & 0.2 & Tipikal di Cilembu & 0.2 \\
\hline & & 0.26 & Tipikal di Luar Cilembu & 0.38 \\
\hline & & 0.24 & Non Tipikal & - \\
\hline \multirow[t]{3}{*}{$\mathrm{K}_{2} \mathrm{O}$} & $\operatorname{mg} 100^{\mathrm{g}-1}$ & 15.43 & Tipikal di Cilembu & 0.8 \\
\hline & & 17.33 & Tipikal di Luar Cilembu & 0.85 \\
\hline & & 16.85 & Non Tipikal & - \\
\hline \multirow[t]{3}{*}{ KTK } & $\mathrm{cmol} \mathrm{kg}^{-1}$ & 23.61 & Tipikal di Cilembu & 0.68 \\
\hline & & 29.48 & Tipikal di Luar Cilembu & 0.98 \\
\hline & & 20.98 & Non Tipikal & - \\
\hline \multirow[t]{3}{*}{ KB } & $\%$ & 51.27 & Tipikal di Cilembu & $0.04 *$ \\
\hline & & 53.95 & Tipikal di Luar Cilembu & $0.01 *$ \\
\hline & & 90.19 & Non Tipikal & - \\
\hline \multirow[t]{3}{*}{$\mathrm{K}$} & $\mathrm{cmol} \mathrm{kg}^{-1}$ & 0.46 & Tipikal di Cilembu & 0.1 \\
\hline & & 0.22 & Tipikal di Luar Cilembu & 0.49 \\
\hline & & 0.16 & Non Tipikal & - \\
\hline \multirow[t]{3}{*}{$\mathrm{Ca}$} & $\mathrm{cmol} \mathrm{kg}^{-1}$ & 7.73 & Tipikal di Cilembu & 0.26 \\
\hline & & 9.78 & Tipikal di Luar Cilembu & \\
\hline & & 10.87 & Non Tipikal & - \\
\hline \multirow[t]{3}{*}{$\mathrm{Mg}$} & $\mathrm{cmol} \mathrm{kg}^{-1}$ & 3.62 & Tipikal di Cilembu & 0.26 \\
\hline & & 6.01 & Tipikal di Luar Cilembu & 0.84 \\
\hline & & 5.74 & Non Tipikal & - \\
\hline \multirow[t]{3}{*}{ Klei } & $\%$ & 41 & Tipikal di Cilembu & 0.5 \\
\hline & & 52 & Tipikal di Luar Cilembu & $0.04 *$ \\
\hline & & 31.5 & Non Tipikal & - \\
\hline \multirow[t]{3}{*}{ Pasir } & $\%$ & 8 & Tipikal di Cilembu & 0.21 \\
\hline & & 8.3 & Tipikal di Luar Cilembu & 0.08 \\
\hline & & 33.83 & Non Tipikal & - \\
\hline \multirow[t]{3}{*}{ Ked Eff } & $\mathrm{cm}$ & 100 & Tipikal di Cilembu & 0.17 \\
\hline & & 100 & Tipikal di Luar Cilembu & $0.05^{*}$ \\
\hline & & 62.5 & Non Tipikal & - \\
\hline \multirow[t]{3}{*}{ Elevasi } & m dpl & 933.64 & Tipikal di Cilembu & $0.0^{*}$ \\
\hline & & 8840.9 & Tipikal di Luar Cilembu & $0.0 *$ \\
\hline & & 758.68 & Non Tipikal & - \\
\hline Tmax & ${ }^{\circ} \mathrm{C}$ & 29.3 & Tipikal di Cilembu & $0.0^{*}$ \\
\hline & & 28.1 & Tipikal di Luar Cilembu & 0.56 \\
\hline & & 29.7 & Non Tipikal & - \\
\hline Tmin & ${ }^{\circ} \mathrm{C}$ & 18.3 & Tipikal di Cilembu & 0.9 \\
\hline & & 13.6 & Tipikal di Luar Cilembu & $0.0^{*}$ \\
\hline & & 18.2 & Non Tipikal & - \\
\hline Trerata & ${ }^{\circ} \mathrm{C}$ & 24.4 & Tipikal di Cilembu & 0.08 \\
\hline & & 21.9 & Tipikal di Luar Cilembu & 0.25 \\
\hline & & 23.4 & Non Tipikal & - \\
\hline$\Delta \mathrm{T}$ & ${ }^{\circ} \mathrm{C}$ & 10.9 & Tipikal di Cilembu & 0.67 \\
\hline & & 14.4 & Tipikal di Luar Cilembu & $0.0^{*}$ \\
\hline & & 10.5 & Non Tipikal & - \\
\hline $\mathrm{CH} 1$ & mm bulan-1 & 52.6 & Tipikal di Cilembu & 0.23 \\
\hline & & 71.75 & Tipikal di Luar Cilembu & 0.12 \\
\hline & & 225.7 & Non Tipikal & - \\
\hline $\mathrm{CH} 2$ & mm bulan-1 & 93.1 & Tipikal di Cilembu & 0.28 \\
\hline & & 132.25 & Tipikal di Luar Cilembu & 0.21 \\
\hline & & 282.1 & Non Tipikal & - \\
\hline $\mathrm{CH} 3$ & mm bulan-1 & 161.91 & Tipikal di Cilembu & 0.45 \\
\hline & & 318.34 & Tipikal di Luar Cilembu & 0.57 \\
\hline & & 268.66 & Non Tipikal & - \\
\hline $\mathrm{CH} 4$ & mm bulan-1 & 236.93 & Tipikal di Cilembu & 0.4 \\
\hline & & 399.46 & Tipikal di Luar Cilembu & 0.57 \\
\hline & & 352.23 & Non Tipikal & - \\
\hline $\mathrm{CH} 5$ & mm bulan-1 & 252.64 & Tipikal di Cilembu & 0.33 \\
\hline & & 320.92 & Tipikal di Luar Cilembu & 0.64 \\
\hline & & 298.94 & Non Tipikal & - \\
\hline
\end{tabular}


Corg=Karbon organik tanah; Ntot=Nitrogen total;; K=Kalium; KTK=Kapasitas tukar kation; KB=Kejenuhan basa; Ca=kalsium; $\mathrm{Mg}=$ Magnesium; Ked.Eff=Kedalaman efektif tanah; Tmax=Temperatur maksimum; Tmin= Temperatur minimum; Trerata= Temperatur rerata; $\Delta \mathrm{T}$ = perbedaan temperatur maksimum dan minimum; $\mathrm{CH} 1-\mathrm{CH} 5=$ Curah hujan pada bulan ke-1 hingga bulan ke-5 periode tanam; * = Uji t berbeda signifikan pada tingkat $\alpha=0.05$

\section{Kesimpulan}

Lahan di Cilembu, Rancakalong dan Sukasari memiliki kadar gula total ubi jalar Cilembu varietas Rancing cenderung lebih tinggi dibandingkan dengan kadar gula total di Cicalengka dan Jalaksana, walaupun perbedaannya tidak signifikan. Namun, lama penyimpanan umbi hingga minggu ke dua setelah panen berpengaruh signifikan terhadap kadar gula total ubi jalar Cilembu.

Antara lokasi budidaya dan lama penyimpanan ubi jalar Cilembu tidak terdapat interaksi terhadap kadar gula total. Namun, faktor lokasi budidaya berperan terhadap kualitas ubi jalar Cilembu walaupun perbedaannya tidak signifikan. Perbedaannya ada pada kadar gula total maksimum dan lama waktu pencapaiannya, dimana umbi yang ditanam di Cilembu, Rancakalong dan Sukasari lebih tinggi dan lama dari pada di lokasi Cicalengka dan Jalaksana.

Terdapat beberapa sifat kimia dan fisik tanah, elevasi serta iklim yang berbeda signifikan di antara lokasi budidaya ubi jalar Cilembu seiring dengan perbedaan kualitas kemanisannya.

\section{Daftar Pustaka}

1] Balai Penelitian Tanah, 2009. Petunjuk Teknis Analisis Kimia Tanah, Tanaman, Air, dan Pupuk. Balai Penelitian Tanah. Badan Penelitian dan Pengembangan Pertanian. Kementerian Pertanian Republik Indonesia, Bogor.

[2] Badan Standarisasi Nasional, 1992. Cara Uji Gula. SNI 012892-1992. Badan Standarisasi Nasional Indonesia, Jakarta.

[3] Çaliskan, M.E., T. Sogut, E. Boydak, E. Ertürk, H. Arioglu. 2007. Growth, yield, and quality of sweet potato (Ipomoea batatas (L.) Lam.) cultivars in the southeastern anatolian and east mediterranean regions of Turkey. Turk J Agri For. 31, pp. 213-227.

[4] [DJKI] Direktorat Jenderal Kekayaan Intelektual, 2013. Indikasi Geografis Ubi Jalar Cilembu. Direktorat Jenderal Hak Kekayaan Intelektual, Kementerian Hukum dan Hak Asasi Manusia Republik Indonesia, Jakarta.

[5] Dutta, T.K., M. Jana, P.R. Pahari,T Bhattacharya, 2006. The Effect of Temperatur, $\mathrm{pH}$, and Salt on Amylase in Heliodiaptomus viduus (Gurney). Turk. J. Zool. 30, pp. 187195

[6] Gaspersz, V., 1991. Metode Perancangan Percobaan untuk Ilmu-ilmu Pertanian, Teknik dan Biologi. CV Armico, Bandung.

[7] Gomes, F., M.K.V. Carr, G.R. Squire, 2005. Effects Of Water Availability and Vine Harvesting Frequency On The Productivity Of Sweet Potato In Southern Mozambique, Radiation Interception, Dry Matter, Production and Partitioning. Expl Agric 41, pp. 93-108.

[8] Hardjowigeno, S., 2007. Ilmu Tanah. Penerbit Akademika Pressindo, Jakarta.

[9] Huang, C.L., W.C. Liao, C.F. Chan, Y.C. Lai, 2014. Storage performance of Taiwanese sweet potato cultivars. J Food Sci Technol. 51 (12), pp. 4019-4025.

[10] Hue, S.M., M.Y. Low, 2015. An Insight into sweet potato weevils management: A Review. Psyche, pp. 1-11.

[11] Kwarteng, E.A., O. Esther, S. Dawson, G.S. Ayernor, VanDen Truong, F.F. Shih, K. Daigle, 2014. Variability of sugars in staple-type sweet potato (Ipomoea batatas L.) cultivars:
The effects of harvest time and storage. Int. J. Food. Prop. 17, pp. 410-420.

[12] Lai, Y.C., C.L. Huang, C.F. Chan, C.Y. Lien, W.C. Liao, 2013. Studies of sugar composition and starch morphology of baked sweet potatoes (Ipomoea batatas L.). J Food Sci Technol. 50(6), pp. 1193-1199.

[13] Laxminarayana, K., K.S. John, 2014. Effect of zinc and magnesium on orange fleshed sweet potato in alfisols of Odisha. India J. Root Crops. 40(1). pp. 1-7.

[14] Lebot V., 2009. Tropical root and tuber crops: Casava, Sweet potato, Yams and Aroids. Crop Production Science in Horticulture. 17. CABI Publishing, Wallingford.

[15] Liu, H., C. Shi, H. Zhang, Z. Wang, C. Shai, 2013. Effects of potassium on yield, photosynthate distribution, enzymes' activity and ABA content in storage roots of sweet potato (Ipomoea batatas Lam.). Australian Journal of Crop Science 7(6), pp. 735-743.

[16] Neduncheshiyan, M., G. Byju, S.K. Jata, 2012. Sweet Potato Agronomy. Fruit, Vegetable and Sereal Science and Biotechnology. 6 (1), pp. 1-10.

[17] Oktiarni, D., 2008. Isolasi, Pemurnian, dan Karakterisasi $\beta$ Amilase Ubi Jalar (Ipomoea batatas (L.) Lam). Tesis. Program Magister Kimia. Institut Teknologi Bandung, Bandung.

[18] Onggo, T.M., 2006. Perubahan Komposisi Pati dan Gula Dua Jenis Ubi Jalar Cilembu Selama Penyimpanan. Jurnal Bionatura 8 (2), pp. 161-170.

[19] Prabawardani, S, A. Suparno, 2015. Water use efficiency and yield of sweetpotato as affected by nitrogen and potassium application. J. Agr. Sci. 7(7), pp. 128-137.

[20] Ramirez, G.P., 1995. Cultivation, Harvesting and Storage of Sweet Pototes Products. On Root, Tuber, Plantain and Bananas in Animal Feeding. pp. 203-215. [terhubung berkala]. http://www.fao.org/ag/aga/agap/frg/ahpp95/95203.pdf [15 Desember 2013]

[21] Ravi, V., R Saravanan, 2012. Crop physiology of sweet potato. Fruit Veg Cereal Sci Biotech 6(1), pp. 17-29.

[22] Risnoyatiningsih, S., 2011. Hidrolisis Pati Ubi Jalar Kuning Menjadi Glukosa Secara Enzimatis. Jurnal Teknik Kimia 5(2), pp. 417-424.

[23] Shekhar, S., D. Mishra, A.K. Buragohain, S. Chakraborty, N. Chakraborty, 2015. Comparative analysis of phytochemicals and nutrient availability in two contrasting cultivars of sweet potato (Ipomoea batatas L.). Food Chem. 173, pp. 957-965.

[24] Siswanto, 2006. Evaluasi Sumberdaya Lahan. Penerbit UPN Press, Surabaya.

[25] Silitonga, P.H., 2003. Peta Geologi Lembar Bandung, Jawa. Direktorat Geologi, Departemen Pertambangan Republik Indonesia, Bandung.

[26] Solihin, M.A., 2007. Potensi Lahan Pengembangan Ubi Cilembu di Kabupaten Sumedang. Jurnal Soilrens. 8(15), pp. 765-774.

[27] Solihin, M.A., S.R.P. Sitorus, A. Sutandi, Widiatmaka, 2016. Biophysic Factors Related to a Local Famous Sweet Potato Variety (Ipomoea batatas L.) Production: A Study Based on Local Knowledge and Field Data in Indonesia. American Journal of Agricultural and Biological Sciences, 11(4), pp. 164-174.

[28] Solihin M.A., 2017. Model Penentuan Kriteria Kesesuaian Lahan Ubi Jalar Cilembu Varietas Rancing Berbasis Karakteristik Spesifik Lokasi. Disertasi. Sekolah Pascasarjana, Institut Pertanian Bogor, Bogor.

[29] Susilawati, S. Nurjanah, A. Putri, 2008. Karakteristik sifat fisik dan kimia ubi kayu (manihot esculenta) berdasarkan lokasi penanaman dan umur panen berbeda. Jurnal Teknologi Industri dan Hasil Pertanian. 13(2), pp. 59-72.

[30] Swamy A.T., J. Omwenga, 2014. Analysis of phytochemical composition of white and purple sweet potato (Ipomoea batatas [L.] Lam) root. Indian J. Adv. Plant. Res. 1 (3), pp. 19-22. 
[31] Tohidin, 2006. Hubungan antara Karakteristik Tanah Sawah Tadah Hujan Berbahan Induk Abu Volkan dengan Kandungan Gula Total Ubi Jalar Nirkum di Beberapa Sentra Ubi Jalar di Jawa Barat. Disertasi. Program Pascasarjana Universitas Padjadjaran, Bandung.

[32] Widodo, Y, S. Wahyuningsih, A. Ueda, 2015. Sweet potato production for bio-ethanol and food related industry in
Indonesia: Challenges for Sustainability. Procedia Chem. 14, pp. 493-500.

[33] Wu, Y, M. Huang, J. Gallichand, 2011. Transpirational response to water availability for winter wheat as affected by soil textures. Agr. Water Manage. 98, pp. 569-576. 